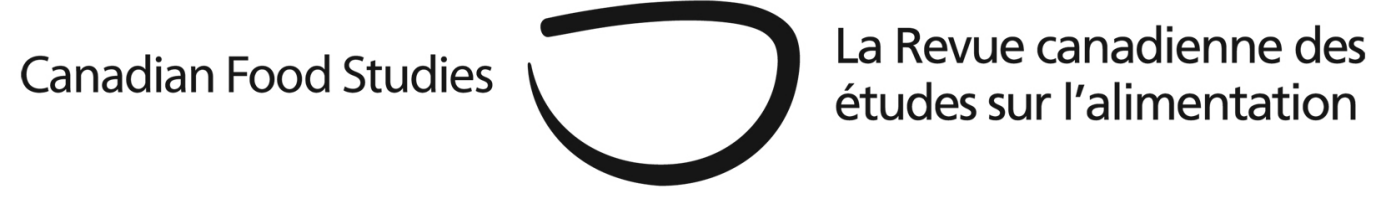

Section VII

Land grabs and agrarian reform

Special Issue: Mapping the Global Food Landscape

\title{
Territorial restructuring and resistance in the Americas
}

\section{Zoe Brent}

Food First

Over the last thirty years, social movements for agrarian reform have struggled to keep up with the profound changes in the structures of land and agricultural production sweeping the continent. In Latin America, what once was a struggle for redistribution, dignity, and social justice in the context of national liberation, has shifted towards a model of "market-led land reform" focussed on productivity, privatization and opening land markets. In the U.S., there have been some important waves of agrarian resistance, but a sense of American exceptionalism has limited agrarian reform discourse from shaping policy, especially during and after the Cold war when it became associated with communism. Today, in both the global North and South, land grabbing and the financialization of land contribute to processes of territorial restructuring and pose broad threats to rural communities, farmers, indigenous peoples, fisherfolk, farmworkers, peasants, and people of color. Consequently, a territorial perspective that broadens alliances and focuses on building political power is emerging among agrarian social movements in Latin America. But (although there are important exceptions) much of the response to the land question in the U.S. remains focussed on land-use planning, zoning, and market-based mechanisms. In part, this reflects a small demographic of farmers, making it very difficult to build a strong political base. 


\section{Territorial restructuring}

After the financial crisis of 2007-08 a flurry of research and media attention on land grabbing ${ }^{1}$ and the financialization of land has put land in the spotlight of development debates and signaled a renewed interest in investing in natural resources (Clapp, 2013; Fairbairn, 2014; Gunnoe, 2014). The high prices on international markets for natural resource-based commodities from gold to soybeans are an important draw for capital. But these market-based explanations mask the ways in which capital penetrates and restructures agrarian production systems-today's agrarian question. To supply international demand for commodities, processes of territorial restructuring are underway from Alaska to Patagonia.

Territorial restructuring is the process by which capital, working closely with the state and/or multilateral/international finance institutions, seeks control over the places and spaces where surplus (wealth) is produced by shaping the institutions, regulations, projects, and social relations that determine economic activities in a particular region (Holt-Giménez, 2008). It reshapes activities of production, extraction, services, and commerce in order to determine how a particular region's wealth will be generated and where it will ultimately accumulate. In this perspective, place refers to the physical areas where production and restructuring happens. Spaces are the socio-political arenas in which different actors vie for power and ultimately restructure the political economic conditions (institutions, laws, policies, endowments) that determine the nature, pace, extent, and direction of surplus. While the dynamics of restructuring vary across space and time, the dominant modes of commodity production are consistently extracting natural resources and profits throughout the region at an unprecedented rate. As a result, land grabbing and financialization are both contributing to this restructuring and further concentration of land and profits in the hands of large corporate interests and financial institutions.

Governments in the North and the South have responded to the commodities boom by opening up political spaces to accommodate corporate interests, which in turn are gulping down water, moving mountains, and obliterating valleys to extract and sow commodities for the international market. Despite the similarities between the processes of agrarian change felt by rural communities in the global North and South, current struggles over land and agendas for agrarian reform have been shaped by divergent trajectories of resistance. In general, the South has moved beyond agrarian reform to a broader territorial perspective while the U.S. has in many cases scaled back demands focussing on land-use planning.

\footnotetext{
${ }^{1}$ On land grabbing, see GRAIN’s 2008 report, “Seized: The 2008 land grab for food and financial security” and their ongoing news and analysis at http://www.farmlandgrab.org. Also: see special issues in the Journal of Peasant Studies 40(5), as well as Globalizations 10(1). For working paper series, see: http://www.iss.nl/ldpi
} 


\section{Challenges of resistance: Argentina}

In Argentina for example, research on land grabbing has called attention to large-scale transactions like the stalled deal for 320,000 hectares with a Chinese company (the Beidahuang State Farms Business Trade Group CO, LTD) in Rio Negro, or the 200,000 hectares acquired by the Saudi Arabian Al-Khorayef Group in the province of Chaco in 2010, which represent the restructuring of "places” to produce commodities for export (GRAIN, 2012). However, the large-scale focus of land grabbing is less helpful in revealing how power and control over land is being concentrated even more frequently at a much smaller scale. According to a 2013 study by the Ministry of Agriculture, Ranching and Fishing (MAGyP), nearly a quarter of Argentina's farming families are engaged in some kind of dispute over their land (Bidaseca et al., 2013). Forty-eight percent of the 857 cases identified are conflicts over parcels of 500 hectares or less.

Neoliberal reforms established a pattern of territorial restructuring that land grabs also reproduce, but are not solely responsible for. President Menem’s (1989-1999) neoliberal reform of agricultural inputs sectors, for example, privatized and concentrated seed markets for maize and soy, selling national seed companies to multinational companies (Newell, 2009). These powerful industry players maintain access to government decision-making processes directly and through representative organizations like the Asociación de Semilleros Argentinos (ASA) and the Foro Argentino de Biotecnología (FAB). Murmis and Murmis (2012) remind us that while much of the trade in commodities is dominated by multinational firms, control of land and resources to produce those commodities happens in a variety of ways, combining domestic and foreign capital, investment “pools,” land leasing, and outright purchase. In the words of Argentine journalist Darío Aranda, "The main problem for peasants and indigenous peoples is not foreign ownership, [but] rather the dominant model of agricultural production” (Aranda, 2011, p. 11). Key actors advancing this dominant model are both foreign and domestic, financial and agricultural, and they rely on influence over political and institutional spaces to do so (Murmis \& Murmis, 2012).

Neoliberal reforms changed the nature of production systems and 'reprimarized' regional and national economies, effectively doubling down on natural resource based primary goods for export (Svampa, 2013). They also changed the meaning of agrarian reform. After WWII rural revolutionary guerilla movements and national liberation struggles included calls for land reform, but according to Veltmeyer (2005), they were often peasant-based, but not peasant-led (p. 307). Then, what Patel and Courville call the "neoliberalization of agrarian reform” led by the World Bank, shifted the emphasis from redistribution to productive efficiency (Courville \& Patel, 2006).

In response, some peasant and indigenous movements have moved beyond agrarian reform to the defense of territories. As threats to peasant and indigenous livelihoods have broadened and intensified, the international peasant movement La Via Campesina "has increasingly learned to think in terms of territory" (Rosset, 2013, p. 726). Thinking in terms of territory has also shaped the framing of the movement, increasingly expressed as an alliance between peasants and indigenous communities united by common threats to their territory from 
the expansion of agribusiness and mining in the context of neoliberal capitalism. Legal claims are used in combination with direct action. These movements are deeply political, incorporating political education into the core of their work and once again basing their claims around justice, dignity, and food sovereignty (see Food Sovereignty section, this issue).

\section{Challenges of resistance: The United States}

Similar to Argentina, processes of territorial restructuring in the U.S. are threatening rural communities. This process is not just a response to market signals, i.e. the "invisible hand." Deliberate policy choices and legal frameworks have subsidized corporate producers and opened the door to a new wave of financial investment in land.

Over the course of the past century, the deepening of the agro-industrial model of commodity production has steadily eroded the base of small-scale farmers in the U.S. However, in recent decades even those farmers who remain are increasingly renting or leasing land (Duffy \& Johanns, 2014), and non-agricultural owners are becoming landlords (Fairbairn, 2014; Gunnoe, 2014; Ross, 2013). As capital faces a crisis of over-accumulation, the financial crisis has left investors searching for new money-making opportunities. What Gunnoe (2014) calls “institutional owners" (p. 2) are speculating on land, steadily driving land prices up (USDA, 2013). These owners include "a broad array of financial actors, including pension funds, endowments, sovereign wealth funds, hedge funds, and private equity firms, among others" (Gunnoe, 2014, p. 2). As the U.S.’s farming population ages, investors like UBS Agrivest, a subsidiary of the biggest bank in Switzerland; The Hancock Agricultural Investment Group (HAIG), a subsidiary of the biggest insurance company in Canada; the Teacher Annuity Insurance Association College Retirement Equities Fund (TIAA-CREF); and Ivy League Universities like Harvard are ready to purchase. Gunnoe highlights a number of reforms that have paved the way for finance in the U.S. including the deregulation of financial markets in the 1970s, reforms in the U.S. tax code in the 1980s, ${ }^{2}$ and declining Federal Reserve interest rates on loans to private banks since the 1980s that provided more money for borrowing and investing (Gunnoe, 2014, p. 10).

In addition to shifts in farmland ownership, a U.S. energy renaissance is undermining rural communities' control over their land. Access to the rights to subsurface minerals is shaped and encouraged by an array of regulations and institutions. For example, on public lands the Bureau of Land Management grants mineral leases, whereas on private lands companies are allowed to negotiate directly with landowners. An army of "land men” have been deployed by private companies to pressure rural residents to sign away mineral rights (Riordan Seville, 2014). Although these regulations have been in place for decades, Obama's "all of the above"

\footnotetext{
${ }^{2}$ For example, the decrease in the tax rate on capital gains from 40 percent in the late 1970 s to 15 percent today-in addition to the Reagan administration's Tax Reform Act of 1986 - has had the effect of shifting the tax burden away from the financial sector and onto industry and labor.
} 
energy strategy has increased their use in order to usher in more energy development from oil, to natural gas, to biofuels. ${ }^{3}$

Even though the U.S. government has supported land reform to combat inequality and land concentration in other countries, a sense of U.S. exceptionalism regarding land has limited the extent to which the idea of agrarian reform has taken root at home (Geisler, 1984). Although it suffered from many shortcomings in its redistributive capacity, the U.S. federal government was still giving land away under the Homestead Act until 1960 (in Alaska) (Geisler, 1984). At the beginning of the $20^{\text {th }}$ century radical agrarian populist farmers organizations and socialist groups put agrarian reform on the table (Goodwyn, 1980 as cited in Geisler, 1984, p. 9-10) and in the 1970s the issue again gained momentum (Holt-Giménez, 2014, p. 4). But, in the context of the Cold War, these socialist associations made it hard for agrarian reform to influence mainstream policy. On the other hand, beginning as early as 1926, land reform was gradually "redefined as land-use planning” (Geisler, 1984, p. 11). In this context and as the farming population has decreased, building the political power necessary to re-radicalize land issues, has been challenging.

Nonetheless organizations are fighting to mobilize U.S. farmers to confront threats of financialization, land grabbing and land concentration. For example Organizations in Washington DC like the NFFC (National Family Farm Coalition) and Rural Coalition/Coalición Rural have focussed for decades on reclaiming control in key political spaces that enable territorial restructuring to undermine small-scale farming communities, for example resulting in a number of new programs under the 1987 Agricultural Credit Act. These efforts developed in conjunction with important work by the Land Loss Prevention Project (LLPP) based in North Carolina and the Federation of Southern Cooperatives/Land Assistance Fund (FSC/LAF) that were founded in 1982 and 1967, respectively, to help African American farmers retain their land amidst ongoing discriminatory practices and economic crises. Some important victories have been won by farmers and allied organizations to prevent loss of land, but the dominant policy conversation about agricultural land in the U.S. is taking place under the banner of farmland preservation, tax incentives, re-zoning agriculture back into cities, and negotiating fair farm leases.

There has been a proliferation of land trusts seeking to use voluntary market-based conservation easements to preserve agricultural land, but in many cases connections with the farmers those easements intend to serve are weak or tension-filled (Beckett \& Galt, 2014). These efforts are developing innovative policy tools to protect farmland, but rather than building a widespread political base, they tend to be spearheaded by non-profit land trusts, food policy councils, or individual landowners and farmers. Additionally, they fail to address the deeper crises in rural areas that make it nearly impossible for farmers to compete with the new institutional owners for land. First, there is a crisis of profitability: for example, over half of all

\footnotetext{
${ }^{3}$ Barack Obama introduced his All of the Above energy strategy in 2012, for more information see http://www.whitehouse.gov/blog/2014/05/29/new-report-all-above-energy-strategy-path-sustainable-economicgrowth
} 
farms in California saw net losses in 2007. Net farm incomes have fallen steadily since their historical high in 1910. Second, there is a crisis of working conditions: unacceptable povertylevel farmworker wages effectively subsidize U.S. agriculture and make competing as a small farmer who pays living wages very difficult. Changing these deeper structural issues will require broad-based political pressure from social movements led by those communities most affected by territorial restructuring.

\section{Moving forward}

A broader historical and geographic perspective of land struggles can inform and shape resistance strategies throughout the Americas. Legal mechanisms and land use laws are essential to solving the land access problem, but the fight is not just about easements, land prices, or zoning. Rather, it is about the ability of people to benefit from the land. Gaining and maintaining control over land and redistribution of power are therefore central to the struggle. And while many organizations are doing important work to mobilize rural and urban communities, and deepen the political nature of resistance in the U.S., there is much to learn. Representing only $2 \%$ of the population, U.S. farmers simply do not have the same potential for mobilization that still exists in much of Latin America, where an average of $15 \%$ of the population still farms (FAO, 2012). Financialization, land grabbing, and land concentration severely threaten both groups throughout the Americas. But these regional similarities also present a political opportunity for strengthening alliances to confront shared threats.

In the face of ongoing processes of territorial restructuring important questions moving forward include: how can alliances among social movements in the North and South, and across sectors and classes be strengthened and expanded to build political power in defense of territories throughout the Americas? And while recognizing geographic and historic differences, how can such alliances be used to exchange knowledge about effective legal and political strategies of resistance to reclaim control of spaces and places, and bring about needed transformation?

\section{References}

Aranda, D. 2011. Tierra Adentro. Revista MU, Año 5(46), 10-1.

Beckett, J., \& Galt, R. (2014). Land trusts and beginning farmers’ access to land: Exploring the relationships in coastal California. Journal of Agriculture, Food Systems, and Community Development, 4(2), 1-17. 
Bidaseca, K., Gigena, A., Gómez, F., Weinstock, A.M., Oyharzábal, E., \& Otal, D. (2013). Relevamiento y sistematización de problemas de tierras de los agricultores familiares en Argentina. Buenos Aires: Ministerio de la Agricultura, Ganadería y Pesca de la Nación (MAGyP).

Clapp, J. (2013). Financialization, distance and global food politics. Paper Presented at the Food Sovereignty: A Critical Dialogue, Yale. Retrieved from http://citeseerx.ist.psu.edu/viewdoc/download?doi=10.1.1.405.193\&rep=rep1\&type=pdf

Courville, M., \& Patel, R. (2006). Introduction and overview: The resurgence of agrarian reform in the twenty-first century. In P. Rosset, R. Patel, \& M. Courville (Eds.), Promised Land: Competing Visions of Agrarian Reform. Oakland: Food First Books.

Duffy, M., \& Johanns, A. (2014). Farmland Ownership and Tenure in Iowa 2012 (No. PM 1983). Iowa State University Extension and Outreach.

Fairbairn, M. (2014). “Like gold with yield”: Evolving intersections between farmland and finance. Journal of Peasant Studies, 41(5), 777-795.

FAO. (2012). World Food and Agriculture (FAO Statistical Yearbook). Food and Agriculture Organization. Retrieved from http://issuu.com/faosyb/docs/fao_statistical_yearbook_2012_issuu

Geisler, C. (1984). A history of land reform in the United States. In C. Geisler \& F. Popper (Eds.), Land Reform, American Style (pp. 7-34). United States of America: Rowman \& Allanheld.

GRAIN. (2012). Land grab deals. Retrieved from http://www.grain.org/article/entries/4479grain-releases-data-set-with-over-400-global-land-grabs

Gunnoe, A. (2014). The political economy of institutional landownership: Neorentier society and the financialization of land. Rural Sociology, 79(4), 478-504.

Holt-Giménez, E. (2008). Territorial Restructuring and the Grounding of Agrarian Reform: Indigenous Communities, Gold Mining and the World Bank (No. 2) (p. 38). Amsterdam: Transnational Institute (TNI), 11.11.11.

Holt-Giménez, E. (2014). This land is whose land? Dispossession, resistance and reform in the United States. Food First Backgrounder, 20(1), 4. 
Murmis, M., \& Murmis, M. R. (2012). Land concentration and foreign land ownership in Argentina in the context of global land grabbing. Canadian Journal of Development Studies, 33(4), 490-508.

Newell, P. (2009). Bio-Hegemony: The political economy of agricultural biotechnology in Argentina. Journal of Latin American Studies, 41, 27-57.

Riordan Seville, L. (2014, August 25). Danger beneath: "Fracking” gas, oil pipes threaten rural residents. NBC News. Retrieved from http://www.nbcnews.com/news/investigations/danger-beneath-fracking-gas-oil-pipesthreaten-rural-residents-n187021

Rosset, P. (2013). Re-thinking agrarian reform, land and territory in La Via Campesina. Journal of Peasant Studies, 40(1), 721-775.

Ross, L. (2013). Down on the Farm. Wall Street: America's New Farmer. Oakland: The Oakland Institute. Retrieved from http://www.oaklandinstitute.org/sites/oaklandinstitute.org/files/OI_Report_Down_on_the Farm.pdf

Svampa, M. (2013). “Consenso de los Commodities” y lenguajes de valoración en América Latina. Nueva Sociedad, 244(Marzo-Abril), 30-46.

USDA. (2013). Land Values 2013 Summary (National Agricultural Statistics Service No. ISSN: 1949-1867). United States Department of Agriculture.

Veltmeyer, H. (2005). The dynamics of land occupations in Latin America. In S. Moyo \& Y. Paris (Eds.), Reclaiming the Land: The Resurgence of Rural Movements in Africa, Asia and Latin America (pp. 285-316). London: Zed Books. 